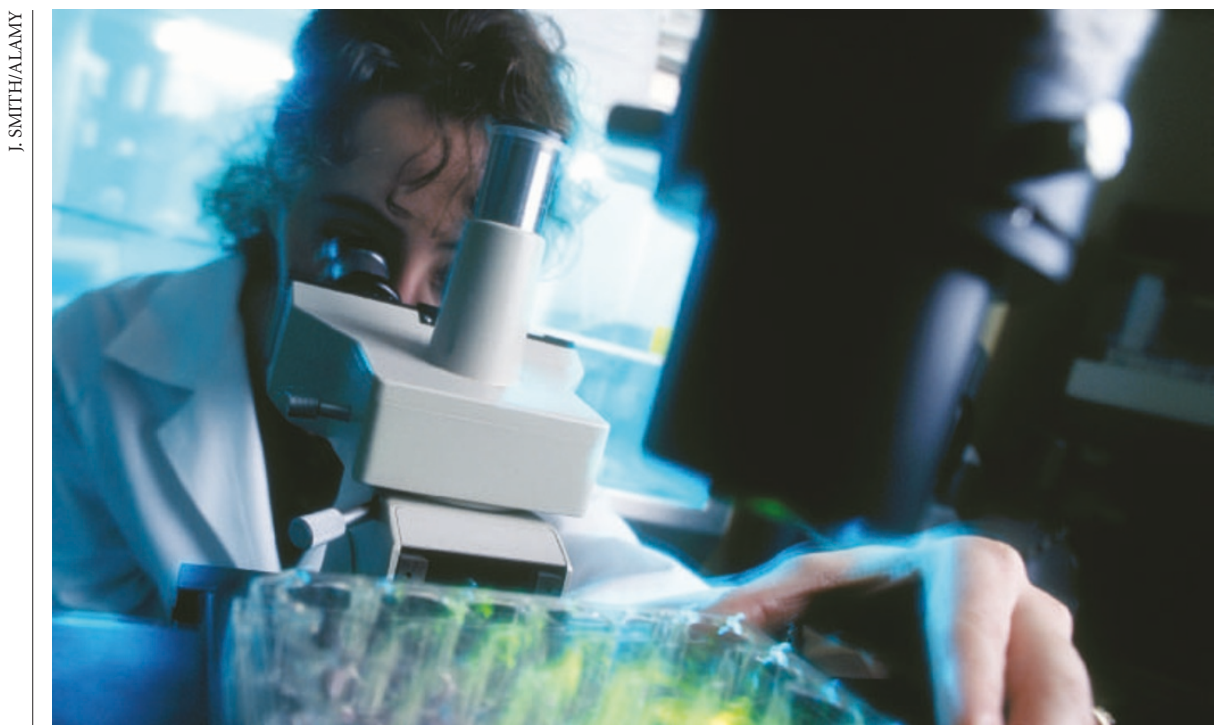

Supporters of a new charter hope that it will give junior researchers badly needed leverage.

\section{Career charter sets out rights of Europe's young scientists}

Quirin Schiermeier, Munich

Ask a hundred young scientists in Europe for their views on their supervisors, funding agencies and university administrators, and you'll get a hundred different answers. But now a 'career charter' is to be published that, its backers say, will encourage higher standards for the treatment of junior researchers.

The European Commission, which intends to release the charter on 11 March, wants the 25 member states of the European Union (EU) to adopt it in the hope that this will help to introduce better and more consistent scientific training across the continent. But some researchers are already expressing doubt that it will make much difference.

The charter declares that all EU researchers, including $\mathrm{PhD}$ students, should be recognized as professionals and treated accordingly. It defines the rights and duties of both young researchers and their supervisors. And it sets out minimum standards for training, employment conditions and socialsecurity coverage for fixed-term researchers working in universities, research institutes and industrial laboratories.

There is considerable demand for such standards. Manyyoung researchers, especially those in eastern and southern Europe, are working under ill-defined terms of employment, without proper contracts, and are effectively at the mercy of their supervisors.

Young scientists' organizations, such as Eurodoc or the Marie Curie Fellowship Organization, are swamped with letters from researchers who have fallen out with their supervisors, or who feel discriminated against on sexual, racial and other grounds.
In January, for example, an Irish biochemistry postdoc working in Austria told Eurodoc that her supervisor had fired her after she had told him that she was pregnant.

Will the charter help her? Sceptics point out that the commission has no legal means to force EU members, or individual universities, to comply with it. But it will invite member states to report annually on their progress in adopting the charter. And supporters say that its very existence will give young researchers some useful leverage.

Christine Heller del Riego, coordinator of the working group on career development for Euroscience, a grass-roots research organization, sees the charter as a badly needed start. Del Riego,who is an electrical engineer at the University Pontificia Comillas in Madrid, is currently drafting a career development strategy for young researchers at her university. "If you can refer to an EU recommendation, then you have a leverage that might really get things moving," she says.

Spain's prime minister, José Luis Rodriguez Zapatero, promised last year to improve the statutory rights of young researchers, for example. But he has since ignored petitions from the FJI, the Spanish young researchers' federation, to go ahead with the promised changes. "Now the EU charter can be used as an additional pressure," del Riego says.

Others say the charter doesn't go far enough. Martin Grabert, head of the Brusselsbased EU liaison office of German research organizations, says he is disappointed by what he terms its "timid, non-committal character", adding: "This is a typical EU approach, a mere minimal consensus with a good chance of falling flat.”
Gene-therapy trials to restart following cancer risk review

Erika Check, Washington

Gene-therapy trials for children suffering from severe combined immunodeficiency disease (SCID) are set to resume in the United States, despite another cancer case in a French trial of the technique.

On 4 March, an advisory meeting in Rockville, Maryland, heard evidence that the cancer risk exposed by the French trial may be specific to one form of the disease, known as X-linked SCID.

The advisory panel recommended that a gene-therapy trial for another variant of the disease, called ADA-SCID, should be allowed to proceed.

The French trial has so far successfully treated six children with X-linked SCID, but three other patients have since developed cancer, and one of these has died. The third of the cancer cases was reported in January, and prompted the US Food and Drug Administration to suspend three US gene-therapy trials on SCID (see Nature 433, 561; 2005).

The leader of the French trial, Alain Fischer of the Necker Hospital for Sick Children in Paris, has already said that he will not continue his trial until he has made changes to the methods he uses to deliver the therapeutic gene to children with X-SCID. But the US panel said that US trials on X-SCID could proceed on patients who have failed to respond to other treatments or are likely to do so.

And it said that, so far, the risk of cancer seems unique to X-SCID, and may not apply to ADA-SCID. At the meeting, oncologist Utpal Dave of the National Cancer Institute described unpublished research suggesting that some of the risk of cancer in the X-SCID trials was related to that form of the disease, and might not appear in other variants of SCID.

Dave's data linked the gene that is missing in children with X-SCID to cancer in mice. He theorized that the method used in the French trial to replace this gene could be increasing the children's risk of cancer. But he found no data to suggest a similar risk for ADA-SCID.

"Although not conclusive, these are the first data that suggest the gene may play a role in these cancers," says Daniel Salomon, a molecular biologist at the Scripps Research Institute in La Jolla, California.

There is one planned US trial in ADA-SCID, led by Donald Kohn of the Childrens Hospital Los Angeles. "I'm glad they agreed that ADA clearly has a safer record to date," Kohn says. 